\title{
Public Participation and Investment Treaties: towards a New Settlement?
}

\author{
Lorenzo Cotula
}

$1 \quad$ A Tale of Two Property Clauses ${ }^{1}$

In the global political transformations that, from the early 199os, followed the end of the Cold War, South Africa transitioned from a white supremacist, authoritarian state to a multi-party democracy. Complex and at times tense negotiations led to the establishment of a new constitutional order - first an interim constitution paving the way to democratic elections, ${ }^{2}$ then the final settlement reflected in the Constitution of $1996 .{ }^{3}$ To mark a decisive break with the country's past, the new constitution affirmed wide-ranging political and socio-economic rights that connect democratic governance to social justice. Property proved a particularly contentious issue in this political transition. The legacy of colonization and apartheid left economic resources - from the country's fertile land to its rich mining industry - in the hands of a few. Redistributive reforms in favour of the historically oppressed Black population, and the restitution of property dispossessed as a result of racially discriminatory laws and practices, were thus an important part of the negotiations. Meanwhile, as the white minority relinquished political power, it sought safeguards to ensure any new majority government would not abuse its position, including with regard to control of economic assets.

With the stakes so high, the development of the new "social contract" was sustained not only by negotiations among political forces, but also by extensive

1 This chapter elaborates on ideas and analysis presented in Lorenzo Cotula, Democratising International Investment Law: Recent Trends and Lessons from Experience (International Institute for Environment and Development, 2015), http://pubs.iied.org/12577IIED.html, and Lorenzo Cotula, 'Democracy and International Investment Law' 3o(2) (2017) Leiden Journal of International Law 351.

2 Constitution of the Republic of South Africa, Act No. 200 of 1993, https://www.justice.gov.za/ legislation/acts/1993-200.pdf (accessed 3 September 2019).

3 Constitution of the Republic of South Africa, Act No. 108 of 18 December 1996, https://www. gov.za/sites/default/files/gcis_document/201409/actı08ofig96s.pdf (accessed 3 September 2019). 
public mobilization: around two million citizens made submissions or signed petitions to influence the drafting of the new Constitution, and the process was accompanied by intense public debates. ${ }^{4}$ Ultimately, agreement on the constitutional property clause could only be reached late in the day, ${ }^{5}$ and the resulting Section 25 of the 1996 Constitution was a compromise. In line with a long tradition of liberal constitutions, the clause affirms that no one may be arbitrarily deprived of property. But the property clause also requires land redistribution, restitution and tenure reform, and it enables authorities to expropriate assets for a public purpose or in the public interest, which it defines as including the commitment to land reform and to promoting equitable access to the country's natural resources. In addition, the clause mandates an "equitable balance" between public and private interests when calculating "just and equitable" compensation, and it lists the economic, social and historical circumstances to be considered - including the market value of the property, its current use, the history of its acquisition, and the purpose of the expropriation. ${ }^{6}$

For two decades, the hopes created by the political transition underpinned an "almost fetishized faith" in the new constitutional order. ${ }^{7}$ In recent years, however, the persistence of racialized poverty and inequality has prompted questions about the extent to which the constitution's ideological and pragmatic foundations can deliver on the promise of a more just society. ${ }^{8}$ The painfully slow progress made with land restitution and redistributive reforms fostered new, extensive and lively debates on amending the constitutional property clause to enable expropriation without compensation for the purposes of land reform. ${ }^{9}$ In late 2019, the government released for consultation

4 Christina Murray, 'A Constitutional Beginning: Making South Africa's Final Constitution' (2001) 23(3) University of Arkansas at Little Rock Law Review 8o9, at 816-817. See also Jeremy Sarkin, 'The Drafting of South Africa's Final Constitution from a Human-Rights Perspective' 47(1) (1999) American Journal of Comparative Law: 67.

5 Murray, 'A Constitutional Beginning' (n 4) 812.

6 Section 25(3) to (7) of the 1996 Constitution.

7 John Comaroff and Jean Comaroff, 'Policing Culture, Cultural Policing: Law and Social Order in Postcolonial South Africa' (2004) 29(3) Law \& Social Inquiry 513, at 515.

8 Joel M. Modiri, 'Conquest and Constitutionalism: First Thoughts on an Alternative Jurisprudence' (2018) South African Journal on Human Rights 1-26.

9 Ruth Hall, 'Expropriation without Compensation, Land Reform and Justice in South Africa', Institute for Poverty, Land and Agrarian Studies (PLAAS) seminar (25 February 2020), available at https://www.youtube.com/watch?v=QpQMdY $3 \mathrm{kRqE}$ (accessed 1 April 2020). See also Nkanyiso Sibanda, 'Amending Section 25 of the South African Constitution to Allow for Expropriation of Land without Compensation: Some Theoretical Considerations of the SocialObligation Norm of Ownership' (2019) 35(2) South African Journal on Human Rights 129. 
a draft constitutional amendment bill whereby, in certain situations, the just and equitable amount of compensation in the light of all relevant circumstances can be nil. ${ }^{10}$

In the 1990s, at around the same time the interim and final constitutions were being developed, the South African government negotiated bilateral investment treaties (BITs) with several states. The BITs established legal standards to protect foreign investment and enabled foreign investors to settle disputes with the host state by means of international arbitration. The government considered these treaties an "important diplomatic signal" that would cement the country's re-admission to the international community after the years of isolation under apartheid. ${ }^{11}$ But the initiative originated from the outside. Concerned that the new government's redistributive agenda would result in the expropriation of British assets, authorities in the United Kingdom initiated the negotiation of South Africa's first BIт. ${ }^{12}$ The treaty was ultimately signed in $1994 \cdot{ }^{13}$ Over the years, South Africa concluded many similar treaties, including with high-income countries such as the Netherlands, Switzerland, Germany and Italy, ${ }^{14}$ and it ultimately pursued a proactive approach to

10 Draft Constitution Eighteenth Amendment Bill (2019), released for public consultation in December 2019 and available at https:/www.parliament.gov.za/storage/app/media/ CommitteeNotices/2019/december/06-12-2019/Draft_advertised.pdf (accessed 1 April 2020). For a discussion, see Theunis Roux, 'The Politics behind South Africa's Property Clause Amendment' (17 Febrary 2020), The Conversation, https://theconversation. com/the-politics-behind-south-africas-property-clause-amendment-131575 (accessed 1 April 2020).

11 Xavier Carim, International Investment Agreements and Africa's Structural Transformation: A Perspective from South Africa (Geneva: South Centre, 2015), https://www.southcentre.int/wp-content/uploads/2015/o8/IPB4_IIAs-and-Africa\%E2\%80\%99s-StructuralTransformation-Perspective-from-South-Africa_EN.pdf (accessed 3 September 2019), p. 4.

12 Lauge N. Skovegaard Poulsen, Bounded Rationality and Economic Diplomacy: The Politics of Investment Treaties in Developing Countries (Cambridge: Cambridge University Press 2015), at p. 169 and, more generally, chapter 7 (discussing South Africa's BIT programme, including against the background of the country's constitutional transition).

13 Agreement between the Government of the United Kingdom of Great Britain and Northern Ireland and the Government of the Republic of South Africa for the Promotion and Protection of Investments [hereinafter South Africa - United Kingdom BIT]. The treaty was signed in Cape Town on 20 September 1994 and entered into force on 27 May 1998. It has since been terminated. The text is available on the UNCTAD International Investment Agreement Navigator: https://investmentpolicy.unctad. org/international-investment-agreements/treaty-files/228o/download (accessed 3 September 2019).

14 UNCTAD International Investment Agreement Navigator (https://investmentpolicy. unctad.org/international-investment-agreements/countries/195/south-africa, accessed 3 September 2019). 
negotiating BITs with countries in the Global South that were of interest to South African businesses. ${ }^{15}$

The treaties' formulation varied considerably, but it was broadly aligned with the BITs major capital exporting states tended to negotiate at that time. This made the treaties eminently relevant to the protection of property: the BITs contained broad definitions of protected "assets", typically including moveable and immoveable property; they set minimum standards of treatment applicable to those assets, such as "fair and equitable treatment", "full protection and security" and rules governing expropriation; and they provided legal remedies for alleged breaches. In regulating these issues, the treaties departed from some of the parameters painstakingly negotiated for the 1996 Constitution. Unlike the constitutional property clause, for example, the expropriation clauses contained in the BITs tended to link compensation to market value alone, and not to reference the wider range of social and historical circumstances listed in the Constitution. ${ }^{16}$ As a result, the treaties provided more generous compensation standards than the 1996 Constitution.

The negotiation of the вIтs did not involve anything like the levels of public participation that characterized the development of the new democratic constitution. The treaties were considered "technical" agreements and were negotiated between government officials. ${ }^{17}$ Commentators have noted that "[li] ttle to no reference is found in the parliamentary debates to any discussions

15 Poulsen, Bounded Rationality and Economic Diplomacy (n 12) 182-183.

16 See, e.g., South Africa - United Kingdom Bit, supra, Article 5(1); Agreement on Encouragement and Reciprocal Protection of Investments between the Republic of South Africa and the Kingdom of the Netherlands (signed in Cape Town on 9 May 1995, entered into force on 1 May 1999 and subsequently terminated), Article 6; Accord entre le Conseil Fédéral Suisse et le Gouvernement de la République d'Afrique du Sud Concernant la Promotion et la Protection Réciproque des Investissements (signed in Berne on 27 June 1995, entered into force on 29 November 1997 and subsequently terminated), Article 5; Treaty between the Federal Republic of Germany and the Republic of South Africa Concerning the Reciprocal Encouragement and Protection of Investments (signed in Cape Town on 11 September 1995, entered into force on 10 April 1998 and subsequently terminated), Article 4(2); Agreement between the Government of the Republic of South Africa and the Government of the Italian Republic on the Promotion and Protection of Investments (signed in Rome on 9 June 1997, entered into force on 16 March 1999 and subsequently terminated), Article 5; and Accord entre l'Union Économique BelgoLuxembourgeoise et la République d'Afrique du Sud Concernant l'Encouragement et la Protection Réciproques des Investissements (signed in Pretoria on 14 August 1998, entered into force on 14 March 2003 and subsequently terminated), Article 5. All texts available at https://investmentpolicy.unctad.org/international-investment-agreements/ countries/195/south-africa (accessed 3 September 2019). 
that took place on bilateral investment treaties". ${ }^{18}$ Just as the country was coming together through consultations and negotiations on a new constitutional order, including to reconcile diverse public and private interests in property relations, a separate process largely below the public radar established special rules to protect assets held by foreign investors - with potentially far-reaching repercussions for the redistributive reforms envisaged in the new political settlement.

Only when businesses activated the treaties to challenge redistributive measures did the issue come under the public spotlight. In 2006, a group of Italian investors initiated arbitral proceedings under the BITs with Italy and Luxembourg, seeking compensation for Black Economic Empowerment measures affecting the mining sector. ${ }^{19}$ The claim was eventually withdrawn, ${ }^{20}$ but the public backlash prompted the South African government to launch a policy review and ultimately terminate most of its investment treaties. ${ }^{21}$ In the new policy approach, investment protection would be primarily ensured through domestic legislation. This policy shift owed much to perceived misalignments between South Africa's BITs and its constitutional property clause. The Protection of Investment Act eventually adopted in 2015 explicitly refers to the objective of redressing historical injustices, ${ }^{22}$ and it governs investment protection by referencing the terms set in the 1996 Constitution. ${ }^{23}$

\section{The Democratic Legitimacy Critique}

In some respects, the complex negotiations and careful balancing act that underlay South Africa's constitutional property clause, and the fast-paced signing of BITs as part of a wider drive to open up the economy, are inextricably

18 Engela C. Schlemmer, 'An Overview of South Africa's Bilateral Investment Treaties and Investment Policy' (2016) 31(1) ICSID Review 167, at 171 (footnote 20).

19 Piero Foresti and Others v. The Republic of South Africa, ICSID Case No. ARB(AF)/O7/1, Award (4 August 2010), para. 1.

$20 \quad$ Ibid., paras. 79-82.

21 See Carim, International Investment Agreements, supra, at 4. According to the UNCTAD International Investment Agreement Navigator, the BIT s terminated include those with Austria, Belgium-Luxembourg Economic Union, Denmark, France, Germany, Italy, Netherlands, Spain, Switzerland and the United Kingdom. See https://investmentpolicy. unctad.org/international-investment-agreements/countries/195/south-africa (accessed 3 September 2019).

22 Protection of Investment Act No. 22 of 15 December 2015, eight preambular paragraph and Sections 8(4) and 12(1)(a).

23 Ibid., Section 10. 
linked to the country's distinctive historical trajectory. But it is not uncommon for property clauses to form the object of difficult constitutional negotiations, particularly in the context of major political change. ${ }^{24}$ Property affects the fundamentals of social and economic organization, as well as the relationship between private interests and public authority. So it is never just a technical legal issue, but a sensitive political one. ${ }^{25}$ In addition, South Africa's accelerated BIT negotiations of the 199os were in line with global trends: after the end of the Cold War, the spread of neoliberal economic thinking and a greater belief in foreign investment as a route to development underpinned a dramatic expansion of the global network of investment treaties, with many states signing treaties in rapid succession. ${ }^{26}$ In these respects, the 199os provided a turning point in the development of international investment law, and many of today's investor-state arbitrations are based on treaties concluded at that time. ${ }^{27}$

The contrasting levels of public participation in the formation of domestic and international instruments relevant to the protection of property are also consistent with wider trends. To be clear, there have been many instances of public scrutiny and participation in the making of international investment treaties. In the 199os, extensive public campaigning on the proposed Multilateral Agreement on Investment contributed to the failure of the negotiations. ${ }^{28}$ At around the same time, Brazil signed several bilateral investment treaties but ratified none due to opposition in Congress, partly because of perceived

24 See also the debates about the right-to-property clause in the drafting of Italy's Constitution of 1948: Stefano Rodotà, Il Terribile Diritto: Studi sulla Proprietà Privata (Bologna: Il Mulino, 199o, 2nd Ed), at 273-421.

25 Francesco Amirante, 'Il Diritto di Proprietà nella Giurisprudenza Costituzionale', paper presented at the seminar IlDiritto di Proprietà nella Giurisprudenza Costituzionale:Incontro Trilaterale delle Corti Costituzionali Italiana, Spagnola e Portoghese (Lisbon, 8-10 October 2009), https://www.cortecostituzionale.it/documenti/convegni_seminari/Amirante_810.10.2009.pdf (accessed 3 September 2019).

26 UnCTAD, Taking Stock of IIA Reform: Recent Developments (Geneva: United Nations Conference on Trade and Development, 2019), IIA Issues Note 3, https://unctad.org/en/ PublicationsLibrary/diaepcbinf2o19d5_en.pdf (accessed 3 September 2019). A diagram presented in the note identifies 1996 as the year in which the greatest number of BIT $\mathrm{s}$ were ever concluded in the period from 1980 (over 200 per year).

27 UnCTAD, Review of ISDS Decisions in 2018: Selected IIA Reform Issues (Geneva: United Nations Conference on Trade and Development, 2019), IIA Issues Note 4, https://unctad. org/en/PublicationsLibrary/diaepcbinf2019d6_en.pdf (accessed 3 September 2019).

28 Jürgen Kurtz, 'NGOs, the Internet and International Economic Policy Making: The Failure of the OECD Multilateral Agreement on Investment' (2002)3 Melbourne Journal of International Law 213. 
inconsistencies with constitutional right-to-property rules. ${ }^{29}$ And since the 1990s, the Colombian Constitutional Court has reviewed the constitutionality of the BITs concluded by the executive - receiving inputs from diverse public and private bodies, and most recently calling on the executive to clarify the interpretation of certain treaty provisions. ${ }^{30}$

Overall, however, historical patterns point to limited levels of public participation. Until relatively recently, many governments handled investment treaty making as a technocratic process, and it seems plausible to speculate that many of the over 3,00o treaties constituting the global stock of investment treaties were concluded with little public participation, and little public debate about the treaties' costs and benefits. In fact, research on investment treaty making in low- and middle-income countries has questioned whether government officials themselves fully considered the costs and benefits of the treaties. ${ }^{31}$ There are no comparable studies assessing the extent to which parliaments and citizens at large understood, considered and debated those costs and benefits; but if the debates occurred, little trace of them appears to be left. It has been noted that, even in "mature" democracies such as the United States (US) and the European Union (EU), economic treaties "often receive far less democratic scrutiny than domestic legislation with the same socio-economic redistributive impact". 32

Practical considerations partly explain these trends: investment treaties involve difficult technical issues and, until the rise of investor-state arbitration, they remained a relatively obscure area of international law. Further, competing demands on parliamentary time and resources can constrain the exercise of any parliamentary powers. Awareness among the general public is often limited, as is publicly available information about developments in treaty negotiations. The ability of citizens and parliaments to shape investment treaty making is particularly limited in those low- and middle-income countries that

29 World Trade Organization, Trade Policy Review - Brazil, Doc. No. Wт/TPR/S/283 (17 May 2013), https://www.wto.org/english/tratop_e/tpr_e/s283_e.pdf (accessed 3 September 2019), at 2.29.

30 See Federico Suárez Ricaurte, 'Judgment C-252 of 2019 of the Constitutional Court of Colombia: Change of Precedent on the Control of BITs', Investment Treaty News (19 September 2019), https://www.iisd.org/itn/2019/og/19/judgment-c-252-of-2019-of-theconstitutional-court-of-colombia-change-of-precedent-on-the-control-of-bits-federicosuarez-ricaurte/ (accessed 3 September 2019).

31 Poulsen, Bounded Rationality (n 12).

32 Joseph H.H. Weiler, 'The Geology of International Law - Governance, Democracy and Legitimacy' (2004) 64 Zeitschrift für Ausländisches Öffentliches Recht und Völkerrecht 547562 , at 556 . 
have traditionally been "rule takers", rather than "rule makers", in what are often asymmetric treaty negotiations. ${ }^{33}$

But legal factors are also at play. Beyond minimalistic rules about the representation of states at treaty negotiation and signature stages, ${ }^{34}$ international law grants states ample latitude to determine the constitutional arrangements through which public authorities make treaties. In each jurisdiction, treatymaking procedures are determined by constitutional law, ${ }^{35}$ and domestic legal systems vary greatly, though they have often enabled treaty making to proceed with limited public oversight. The role of parliaments in treaty ratification illustrates this point. In many polities, parliamentary approval is an explicit legal requirement for ratification - in the EU, for example. ${ }^{36}$ But some other constitutions allow the government to conclude investment treaties with relatively little parliamentary involvement. In South Africa, the 1996 Constitution requires parliamentary approval for some types of treaties but not others (namely, treaties of a "technical, administrative or executive nature", and treaties that do not require ratification), ${ }^{37}$ and research suggests the BITs were deemed to fall in the latter category. ${ }^{38}$

In these contexts, the legal channels for parliament to shape investment treaties pale in comparison to parliament's central role in national law making. Geared towards facilitating efficient treaty making, constitutional arrangements that provide parliaments with a limited role seem rooted in an era when international treaties tended to have more limited impact on national governance. Over the past few decades, international law has expanded and deepened its reach in an increasingly broad gamut of domestic policy domains. International investment law illustrates this trend: foreign investors have relied on investment treaties to settle disputes over public action in wide-ranging

33 Eyal Benvenisti, 'Democracy Captured: The Mega-Regional Agreements and the Future of Global Public Law' (2016)23(1) Constellations 58. On the link between rule making / taking and GDP levels, see Wolfgang Alschner and Dmitriy Skougarevskiy, 'Mapping the Universe of International Investment Agreements' (2016) 19(3) Journal of International Economic Law 561.

34 Vienna Convention on the Law of Treaties (Vienna, 23 May 1969) (VCLT), Article 7.

35 However, the VCLT clarifies that: 'A State may not invoke the fact that its consent to be bound by a treaty has been expressed in violation of a provision of its internal law regarding competence to conclude treaties as invalidating its consent unless that violation was manifest and concerned a rule of its internal law of fundamental importance'. vCLT, supra, Art. 46(1).

36 Treaty on the Functioning of the European Union (as amended), Official Journal of the European Union 2008/C115/o1 (2008), Articles 207(2)-(3) and 218(6).

$37 \quad 1996$ Constitution, supra, Section 231.

38 Poulsen, Bounded Rationality and Economic Diplomacy, (n 12) 181; Schlemmer, 'An Overview of South Africa's Bilateral Investment Treaties', (n 18) at 170-171. 
areas of social, economic and political organization - from industrial policy to taxation, public health, water access, agrarian reform and environmental protection, to name but a few examples.

Compensation is the most common remedy in international investment law: if an arbitral tribunal finds that a state has breached its legal obligations and adversely affected a foreign investment, it typically orders the government to compensate the investor for actual and/or projected losses. Legal scholarship has noted that arbitral tribunals have the power to order specific performance, ${ }^{39}$ and some arbitral awards have done so in practice - for example, requiring states to return land to expropriated investors. But in these circumstances, the tribunals have also allowed states to pay damages instead. ${ }^{40}$ This primacy of monetary relief in international investment law means that states can ultimately take the measures they deem desirable and compensate investors for losses.

However, this observation obscures some far-reaching implications. By affecting how the costs of public action are distributed in society, compensation requirements can directly interrogate the collective sense of justice. For this reason, those requirements can be an important - and often contested - part of the social contract, as reflected in the lively debates about South Africa's constitutional property clause. Further, the emphasis many investment treaties place on full market value, and the large compensation amounts awarded by some arbitral tribunals, mean that complying with investment treaty obligations can create a significant burden on public finances, particularly in low- and middle-income countries, with possible knock-on effects in diverse policy areas that hinge on government spending. ${ }^{41}$ And the risk of expensive investor-state disputes could discourage states from taking action in the first place, thereby affecting space for democratic decision making - a "regulatory chill" concern that is explicitly mentioned in some arbitral decisions, ${ }^{42}$ and sustained by a growing body of evidence. ${ }^{43}$

39 Farshad R. Dizgovin, 'Foundations of Specific Performance in Investor-State Dispute Settlement: Is It Possible and Desirable?' (2016)28(1) Florida Journal of International Law 1. Bernard von Pezold and Others v. Republic of Zimbabwe, ICSID Case No. ARB/10/15, Award (28 July 2015), at 1020.

41 Suárez Ricaurte, 'Judgment C-252 of 2019 of the Constitutional Court of Colombia' (n 3o) (estimating that the aggregate value of ongoing arbitration claims against Colombia amounts to $10 \%$ of the country's entire national budget for 2019). William Ralph Clayton, William Richard Clayton, Douglas Clayton, Daniel Clayton and Bilcon of Delaware Inc. v. Government of Canada, PCA Case No. 2009-04, Dissenting Opinion of Professor Donald McRae (10 March 2015), at 48, 51; David Aven and Others v. Republic of Costa Rica, ICSID Case No. UNCT/15/3, Award (18 September 2018), para. 172. See for example Stuart G. Gross, 'Inordinate Chill: BITs, Non-nafta MITs, and HostState Regulatory Freedom: An Indonesian Case Study' 24(3)(2003) Michigan Journal of 
Much investment law debate on these issues focuses on the relationship between investors and states - casting the state either as a benevolent regulator unduly constrained by investment protection standards, or as an opportunistic predator requiring international discipline. But a more realistic account needs to consider the wider constellations of actors that are involved in, affected by or concerned about investment processes. ${ }^{44}$ This perspective recognizes that investments can affect the rights of workers, public service users, Indigenous Peoples or local residents, and foster multi-actor disputes at odds with the binary framing of investor-state dispute settlement; that disaggregated state apparatuses (e.g. local and central government agencies; different sectoral ministries; executive, legislative and judicial powers) can respond to different and possibly conflicting concerns, often leading to inconsistent state action in the face of contrasting interests; and that diverse political economy factors often produce variegated patterns of state conduct that, depending on the situation, may - or may not - advance the "public interest".

In these circumstances, pressure from organized citizens - including those most directly affected by investments - can be an important driver of public action, or even its prerequisite. And indeed, local protests have formed part of the factual fabric of several investor-state arbitrations, ${ }^{45}$ as have court

International Law 893; Kyla Tienhaara, 'What You Don't Know Can Hurt You: InvestorState Disputes and the Protection of the Environment in Developing Countries' (2006)6(4) Global Environmental Politics 73; Kyla Tienhaara, 'Regulatory Chill and the Threat of Arbitration: A View from Political Science', in Chester Brown and Kate Miles (Eds), Evolution in Investment Treaty Law and Arbitration (Cambridge University Press, 2011), pp. 6o6-628; Zoe Phillips Williams, 'Investor-State Arbitration in Domestic Mining Conflicts' (2016) 16(4) Global Environmental Politics 32; Gus Van Harten and Dayna Nadine Scott, 'Investment Treaties and the Internal Vetting of Regulatory Proposals: A Case Study from Canada' (2016)7 Journal of International Dispute Settlement 92; Jane Kelsey, 'Regulatory Chill: Learnings from New Zealand's Plain Packaging Tobacco Law' (2017)17(2) QUT Law Review 21-45.

44 On the multiple actors affected by investment processes, see Nicolás M. Perrone, 'The International Investment Regime and Local Populations: Are the Weakest Voices Unheard?' (2016)7(3) Transnational Legal Theory 383. See also Lorenzo Cotula, Human Rights, Natural Resource and Investment Law in a Globalised World: Shades of Grey in the Shadow of the Law (Abingdon and New York: Routledge, 2012), mapping actors and relations concerning the Chad-Cameroon oil development and pipeline project (pp. 27-37).

45 See for example Técnicas Medioambientales Tecmed sA v. The United Mexican States, ICSID Case No. ARB(AF)/oo/2, Award (29 May 2003), paras. 42, 49, 105(4)-(5), 106-10, 127-44; Abengoa S.A. y cofides S.A. v. Estados Unidos Mexicanos, ICSID Case No. ARB(Af)/og/ 2, Award (18 April 2013), paras. 194-208, 587; Copper Mesa Mining Corporation v. The Republic of Ecuador, PCA Case No. 2012-2, Award (15 March 2016), paras. 4.12, 4.32-35, 4.45 , 4.52, 4.57, 4.69, 4.72, 4.82, 4.87, 4.95, 4.107, 4.111-12, 4.115, 4.141, 4.154-55, 4.194-95. 
proceedings initiated by local groups or non-governmental organizations. ${ }^{46}$ One question, then, is whether the international protection of foreign investment, and the related compensation requirements, can make it more difficult for citizens to obtain what they seek from public authorities - in effect, adding a multi-actor dimension to longstanding debates about regulatory chill. Methodological challenges constrain systematic evidence. But reports suggest that, on some occasions at least, concerns about costly arbitration proceedings may have been a factor in government responses to public protests. ${ }^{47}$

That international treaties can affect available policy options should not surprise: treaties create binding obligations, so states may be legally required to take some measures and proscribed from taking others. But unlike many other international agreements, investment treaties usually restrict states' ability to unilaterally terminate treaties, or (for treaties involving more than two parties) to withdraw from them. Many termination clauses provide that the treaty can only be terminated after 10 or even 20 years; and that, once the treaty has been terminated, it continues to apply to investments made while the treaty was in force, usually for an additional 10 or 20 years. ${ }^{48}$ Although the treaties can be and often are revised or terminated by agreement between the state parties, these restrictions on unilateral action have led some to draw parallels between investment treaties and constitutional safeguards that, in liberal democracies, seek to outlast electoral cycles and prevent a "tyranny of the majority", by entrenching rights that even majority vote cannot overturn. ${ }^{49}$ Critical commentators observed that this disciplining of democratic decision making was in fact a deliberate aim of the international investment regime, linked to ordoliberal conceptions of political organization that aim to shelter economic governance from the exercise of popular sovereignty. ${ }^{50}$

46 See for example Chevron Corporation and Texaco Petroleum Corporation v. The Republic of Ecuador (PCA Case No. 2009-23), and Infinito Gold Ltd. v. Republic of Costa Rica (ICSID Case No. ARB/14/5).

47 See, e.g., Mitra Taj, 'Peru Hopes to Revive Bear Creek Mine, Avoid Legal Battle', Reuters (14 August 2014), www.reuters.com/article/peru-bear-creek-minng-santaanaidUSL2NoQLooZ20140815 (accessed 3 September 2019) (reporting that the Peruvian government 'hope[d] to ease local opposition to [a] silver mine and avoid a costly legal battle with the company').

48 Joachim Pohl, Temporal Validity of International Investment Agreements: A Large Sample Survey of Treaty Provisions (Paris: OECD, 2014), http://www.oecd.org/investment/ investment-policy/WP-2013_4.pdf (accessed 3 September 2019).

49 David Schneiderman, Constitutionalizing Economic Globalization: Investment Rules and Democracy's Promise (Cambridge: Cambridge University Press, 20o8), e.g. at 4, 9-10, 37-45.

50 Quinn Slobodian, Globalists: The End of Empire and the Birth of Neoliberalism (Harvard University Press, 2018); Ntina Tzouvala, 'The Ordo-Liberal Origins of Modern International 
However, constitutions - at least in theory - embody the social contract, and their drafting or modification is (or should be) carried out through mechanisms that "guarantee extraordinarily high levels of democratic consent". 51 These considerations bring us back to South Africa's transition to multi-party democracy, and the contrasting levels of public participation that characterized the development of the new constitution, and of the country's stock of BITs. In recent years, the extensive recourse to investment treaties, and to investor-state dispute settlement, in wide-ranging policy areas worldwide, and the varying but often limited public participation in the historical development of those treaties, have fostered critiques of the democratic legitimacy of the investment treaty regime. In fact, a United Nations human rights expert openly questioned that legitimacy. ${ }^{52}$ These critiques correlate with wider concerns about the prevalence of "managerial" approaches to the governance of public affairs - whereby elections are held, opinions are expressed and governments change, but important decisions are taken by the executive in the name of technocratic considerations, often outside the established channels for democratic decision making. ${ }^{53}$

The rise of such critiques has been associated with the proliferation of investor-state arbitrations, because arbitral tribunals usually comprising three private individuals are often called to review the conduct of democratically elected governments or legislatures, or of national courts, based on treaty standards that leave significant scope for discretion. ${ }^{54}$ And while reforms of arbitration rules have increased transparency in many contexts, there are enduring concerns about opaque aspects of investor-state arbitration, for example in

Investment Law: Constructing Competition on a Global Scale' (2020) European Yearbook of International Economic Law (John D. Haskell and Akbar Rasulov, eds), pp. 37-54.

51 Jürgen Kurtz, 'Building Legitimacy through Interpretation in Investor-State Arbitration: On Consistency, Coherence, and the Identification of Applicable Law', in Zachary Douglas, Joost Pauwelyn and Jorge E. Viñuales (Eds), The Foundations of International Investment Law: Bringing Theory into Practice (Oxford and New York: Oxford University Press, 2014), pp. $257-296$, at 263 .

$5^{2}$ Report of the Independent Expert on the Promotion of a Democratic and Equitable International Order, UN Doc. A/70/285 (5 August 2015), www.un.org/en/ga/search/view doc.asp?symbol=A/70/285 (accessed 3 September 2019), at 10.

53 Colin Crouch, Post-Democracy (Cambridge and Malden: Polity, 2004); and Colin Crouch, 'Democracy at TTIP-ing point: Seizing a Slim Chance to Reassert Democratic Sovereignty in Europe', The Progressive Policy Think Tank (6 December 2014), https://www.ippr.org/ juncture/democracy-at-a-ttiping-point-seizing-a-slim-chance-to-reassert-democraticsovereignty-in-europe (accessed 3 September 2019).

54 For a discussion of these issues, see 'Interview with Toby Landau QC' (28 March 2014), www.youtube.com/watch?v=bJaoADpICjs (accessed 3 September 2019). 
relation to the terms of negotiated settlements. ${ }^{55}$ Questions have also been raised in connection with the tribunals' jurisprudential approaches, as arbitral awards have often struggled to make sense of the inherently political nature of democratic contestation and responsive public action in investment processes. ${ }^{56}$ Ultimately, however, the questions interrogate the democratic legitimacy of the treaties themselves, the legal standards they establish and the processes through which they were concluded.

\section{$3 \quad$ Towards a New Settlement?}

As investor-state arbitrations have made the costs of the treaties more apparent, public scrutiny of investment treaty making has increased. Mapping these evolutions requires us to consider not only the formal rules of democratic governance and public participation, but also the practices of citizen activism. Rules-based conceptions of democracy tend to focus on the legal rights and liberties associated with citizenship, and the legal arrangements that shape relations of public accountability, including electoral processes and parliamentary oversight. ${ }^{57}$ On the other hand, practice-based conceptions focus on the real-life experiences of contestation and negotiation whereby citizens appropriate political spaces to influence the management of public affairs. ${ }^{58} \mathrm{In}$ these latter conceptions, democracy is not a static situation defined by formal rules and procedures, but a never achieved, always evolving practice centred on debate, deliberation and dissent. ${ }^{59}$ While legal training might make lawyers

55 Lise Johnson and Brooke Skartvedt Güven, 'The Settlement of Investment Disputes: A Discussion of Democratic Accountability and the Public Interest' (13 March 2017) Investment Treaty News https://cf.iisd.net/itn/2017/o3/13/the-settlement-of-investmentdisputes-a-discussion-of-democratic-accountability-and-the-public-interest-lisejohnson-and-brooke-skartvedt-guven/.

56 David Schneiderman, 'Investing in Democracy: Political Process and International Investment Law' (2010) University of Toronto Law Journal 6o(4): 909-940; Jonathan Bonnitcha and Zoe Phillips Williams, 'State Liability for 'Politically' Motivated Conduct in the Investment Treaty Regime' (2019) Leiden Journal of International Law 33(1): 77-100. See also James Tully, 'On Modern and Diverse Citizenship', in James Tully (Ed), On Global Citizenship:James Tully in Dialogue (London and New York: Bloomsbury, 2014), pp. 3-100, at $14-15$.

$58 \quad$ Ibid., at 36 .

59 John Gaventa, 'Triumph, Deficit or Contestation? Deepening the 'Deepening Democracy' Debate', (2006) Institute of Development Studies Working Paper 264, https://www. ids.ac.uk/publications/triumph-deficit-or-contestation-deepening-the-deepeningdemocracy-debate/ (accessed 3 September 2019). On the relationship between democracy 
instinctively inclined to address rules-based aspects, considering practicebased dimensions as well is essential to develop a more realistic account of democratic governance.

In fact, rules- and practice-based dimensions are interlinked, because activism and contestation often precede, and sometimes contribute to, changes in the formal rules. These interrelations are apparent, for example, in the historical emergence of non-disputing party ("amicus curiae") submissions in the context of investor-state arbitration: over the years, actions by nongovernmental organizations ${ }^{60}$ ultimately fostered legal change in the form of interpretive statements, ${ }^{61}$ reforms to arbitration rules ${ }^{62}$ and the inclusion of transparency provisions in a new generation of investment treaties. ${ }^{63} \mathrm{But}$

and dissent, see Jacques Rancière, "Introducing Disagreement" (2004) Algelaki:Journal of the Theoretical Humanities 9(3): 3-9.

6o Methanex Corporation v. United States of America, United Nations Commission on International Trade Law (UNCITRAL) arbitration under North American Free Trade Agreement (NAFTA) Chapter 11, Petition to the Arbitral Tribunal Submitted by the International Institute for Sustainable Development (25 August 200o); Decision of the Tribunal on Petitions from Third Persons to Intervene as 'Amici Curiae' (15 January 2001); Amicus Curiae Submissions by the International Institute for Sustainable Development (9 March 2004); Submission of Non-Disputing Parties Bluewater Network, Communities for a Better Environment and Center for International Environmental Law (9 March 2004); and Letter from the Tribunal (6 April 2004). See also Aguas Argentinas, S.A., Suez, Sociedad General de Aguas de Barcelona, S.A. and Vivendi Universal, S.A. v. The Argentine Republic, International Centre for Settlement of Investment Disputes (ICSID) Case No. ARB/o3/19, Order in Response to A Petition for Transparency and Participation as Amicus Curiae (19 May 2005).

61 North American Free Trade Agreement: Statement of the Free Trade Commission on Non-Disputing Party Participation (7 October 2003), http://www.naftaclaims.com/commissionfiles/Nondisputing-en.pdf. On the relationship between this statement and the initial amicus curiae submission made in the case Methanex Corporation v. United States of America, supra, see James Harrison, 'Human Rights Arguments in Amicus Curiae Submissions: Promoting Social Justice?', in Pierre-Marie Dupuy, Francesco Francioni and Ernst-Ulrich Petersmann (Eds), Human Rights in International Investment Law and Arbitration (Oxford University Press, 2009), pp. 396-421, at 402.

62 ICSID Rules of Procedure for Arbitration Proceedings (Arbitration Rules), Article 37(2); and Antonio R. Parra, The History of ICSID (Oxford University Press, 2012), at 249-250. See also the UNCiTRAL Rules on Transparency in Treaty-based Investor-State Arbitration (30 July 2013), Article 4; and the United Nations Convention on Transparency in TreatyBased Investor-State Arbitration (New York, 10 December 2014, into force 18 Ocotber 2017) ("Mauritius Convention").

63 See for instance the US Model Investment Treaty of 2004, Article 28(3), and the US Model Investment Treaty of 2012, Article 28(3). See also, for example, the 2006 Agreement Between Canada and the Republic of Peru for the Promotion and Protection of Investments (14 November 2006, into force 20 June 2007), Article 39. 
apart from the narrowly circumscribed import of amicus curiae submissions, the dispute settlement stage intervenes late in the policy process, and recent years have witnessed more sustained efforts to promote public participation in policy decisions concerning investment treaties themselves. Here too, political space had to be claimed, and the institutions of both direct and representative democracy have provided arenas for these struggles.

In the EU, after the Lisbon Treaty came into effect, ${ }^{64}$ the European Parliament has leveraged its greater say in economic treaty making to provide specific guidance on investment treaty policy, ${ }^{65}$ and on individual treaty negotiations. ${ }^{66}$ In so doing, it reclaimed political space in its relations with other EU institutions, particularly the European Commission. ${ }^{67}$ Outside parliamentary processes, public advocacy has mobilized public protests, media outreach and social media campaigns, but also the legal arrangements of direct democracy. In one particularly prominent action, activists filed a request for a "European Citizens' Initiative" on two major proposed investment treaties - the then proposed Transatlantic Trade and Investment Partnership (TTIP) with the United States, and the Comprehensive Economic and Trade Agreement (CETA) with Canada. ${ }^{68}$ The

642007 Treaty of Lisbon Amending the Treaty on European Union and the Treaty Establishing the European Community, Official Journal of the European Union 2007/ C3o6 (2007).

65 European Parliament Resolution of 6 April 2011 on the Future European International Investment Policy, Procedure File 2010/2203(INI) (2011), www.europarl.europa.eu/sides/ getDoc.do?pubRef=-//EP//TEXT+TA+P7-TA-2011-0141+o+DOC+XML+Vo//EN $($ accessed 3 September 2019).

66 See for example European Parliament Resolution of 9 October 2013 on the EU-China Negotiations for a Bilateral Investment Agreement, Procedure File 2013/2674(RSP) (2013), www.europarl.europa.eu/sides $/$ getDoc.do?type $=$ TA\&language $=$ EN\&reference $=\mathrm{P}_{7}-\mathrm{TA}-$ 2013-411 (accessed 3 September 2019).

67 See for example European Parliament Resolution of 30 May 2018 on the Annual Report on the Implementation of the Common Commercial Policy, para. 5 (arguing "that Parliament must be involved and must be kept fully informed from the onset of all trade negotiations, prior to the adoption of negotiating guidelines, in a timely manner, at all stages of the mandate conferral, and of the negotiation and implementation of trade agreement"). See also Christilla Roederer-Rynning, 'Parliamentary Assertion and Deep Integration: The European Parliament in the ceta and TTIP Negotiations' (2018) 30(5)-(6) Cambridge Review of International Affairs 507.

68 A European Citizens' Initiative is an invitation to the European Commission to propose legislation. A citizens' initiative must be backed by at least one million EU citizens, coming from at least seven member states. The legal basis for the European Citizens' Initiative is provided by Article 11(4) of the Treaty on the European Union, Article 24(1) of the Treaty on the Functioning of the European Union, and Regulation No. 211/ 2011 of the European Parliament and of the Council of 16 February 2011 on Citizens' Initiatives. See also Fernando Mendez and Mario Mendez, 'The Promise and Perils of 
European Commission rejected this request, ${ }^{69}$ but campaigners pushed ahead with the petition as a tool to catalyse public mobilization, ultimately collecting millions of signatures. ${ }^{70}$

While systematic data is not available, parliamentary and citizen scrutiny of investment treaty making often seems more difficult in many low- and middleincome countries, especially where public awareness levels are lower and political space for contestation more constrained. But there are numerous documented instances. In Malaysia, for example, a coalition of non-governmental organizations, consumer groups, public health organizations and trade associations conducted campaigning, awareness raising, alliance building and government lobbying to advocate on the investment chapter of what would ultimately become the Comprehensive and Progressive Trans-Pacific Partnership (СР TPP), with parliamentarians also scrutinizing the negotiations. ${ }^{71}$ And in Myanmar, a transnational alliance of activists conducted advocacy on a proposed bilateral investment treaty with the EU. ${ }^{72}$ There have also been many documented instances of parliamentary and citizen engagement with investment treaty making in Africa and Latin America. ${ }^{73}$

Direct Democracy for the European Union' (2017)19 Cambridge Yearbook of European Legal Studies 48.

69 European Commission, 'Your Request for Registration of a Proposed Citizens' Initiative Entitled 'sтор ттір" [motivated refusal to register the citizens' initiative], 10 September 2014, C(2014) 6501 final, https://www.euractiv.com/section/ trade-society/news/commission-opposes-european-citizens-initiative-against-ttip/ (accessed 3 September 2019).

70 For a critique of public mobilization around tTIP and CETA, see Gabriel Siles-Brügge, 'Transatlantic Investor Protection as a Threat to Democracy: The Potency and Limits of an Emotive Frame' (2018) 30(5)-(6) Cambridge Review of International Affairs 464.

71 Comprehensive and Progressive Trans-Pacific Partnership (Santiago, 8 March 2018). See Fauwaz Abdul Aziz, Advocacy on Investment Treaties: Lessons from Malaysia (London: International Institute for Environment and Development, 2015), pubs.iied.org/12581IIED. html (accessed 3 September 2019); and Lorenzo Cotula and Celine Tan, "Civil Society and Investor-State Dispute Settlement", in State of Civil Society Report 2017 (CIVIcUs, 2017) http:// www.civicus.org/documents/reports-and-publications/SOCS/2017/essays/civil-society-andinvestor-state-dispute-settlement.pdf (accessed 3 September 2019).

72 See, e.g., 'Cso Statement on Myanmar Investment Treaties', 25 June 2014, https:// www.tni.org/en/declaration/cso-statement-myanmar-investment-treaties (accessed 3 September 2019); 'Open Letter from Myanmar Civil Society on EU-Myanmar Investment Agreement: Concerns of Myanmar Civil Society on 'Sustainability Impact Assessment' (SIA) in Support of an Investment Protection Agreement between EU and Myanmar', 6 April 2016, http://www.s2bnetwork.org/myanmar-sia/ (accessed 3 September 2019).

73 See, e.g., Xinhua, 'African Campaigners Urge Review of Foreign Investment Laws to Protect Sovereignty', XinhuaNet (24 April 2019), http://www.xinhuanet.com/english/ 2019-04/24/c_138005778.htm (accessed 3 September 2019); Paulina Acevedo Menanteau, 
These developments point to an ongoing renegotiation of relations between the executive, parliaments and organized citizens with regards to the making of economic treaties: once a largely technocratic process, treaty negotiations can now involve extensive public mobilization, and many parliaments are increasingly assertive in treaty formation processes well beyond the ratification stage. That said, high-profile mobilization around a relatively small number of particularly encompassing, and thus visible, mega-treaties covering both trade and investment - such as CETA and CPTPP - should not obscure the enduring challenges of limited public awareness, scrutiny or participation surrounding the development and operation of many вiтs. Further, the real impacts of the increased parliamentary and citizen activism are yet to be systematically assessed - including whether public engagement is affecting policy outcomes, or primarily lending democratic legitimacy to policies that present substantial continuity with previous practice. From a legal standpoint, much work remains to be done to explore what legal arrangements can enable both effective democratic scrutiny and efficient treaty making.

Faced with substantial arbitration claims, many states have sought to "recalibrate" the content of their investment treaties. ${ }^{74}$ Depending on how the "new-generation" treaties are interpreted and applied, these developments could shift the balance between investment protection and public regulation. But addressing the challenge posed by the democratic legitimacy critiques requires more than a technical fix, or a reflection on options to reformulate the legal standards featured in the treaties. While debates about investment treaties are often framed in technical terms, choices on whether to sign, revise or terminate the treaties, and in what form, are eminently political: they affect the boundaries of the protection of property, the parameters for the lawful exercise of public authority, and the ways public and private interests are reconciled. Diverse interest groups can legitimately have different positions on acceptable balances between competing policy considerations. These political stakes turn the spotlight on how policy decisions are made - including who participates in decision-making processes, and with what effects. They interrogate the avenues for democratic oversight of the international legal architecture underpinning global economic governance. As momentum for increased public participation grows, it seems an opportune time for scholars and practitioners to take stock of international experience, distil lessons and chart possible trajectories for moving forward.

“Chile Da Ejemplo de Cómo Enfrentar el TPP", Servindi (12 September 2015), https://www. servindi.org/actualidad/140261 (accessed 3 September 2019).

74 José E. Alvarez, 'The Return of the State' (2011) 20(2) Minnesota Journal of International Law 223. 